\title{
Research on the Creative Development of Sports Tourism in Ancient Villages in Xiangxi
}

\author{
Lizhong Wen \\ College of Sports and Science, Jishou University, Jishou, Hunan 416000 \\ wenlizhong1107@163.com
}

Keywords: Xiangxi; Ancient; Villages Sports; Tourism Creative development

\begin{abstract}
In the great tide of social economic and cultural development, sports tourism is becoming the essential component of the sustainable development of the tourism industry. Tourism is the leading industry in Xiangxi, and sports tourism is a major feature. In order to further develop the tourism industry and speed up the pace of economic development, Xiangxi should develop multi-level sports and tourism in ancient villages, display the national cultural characteristics, and improve the level of sports tourism industry development.
\end{abstract}

\section{Introduction}

The ancient villages in Xiangxi are rich in sports and cultural tourism resources. In the development of sports tourism, xiangxi should grasp the present situation of ancient villages and sports tourism development in an all-round way, take sports tourism connotation as the base, take feasible method means, develop sports tourism of ancient villages creatively, continuously integrate new elements for sports tourism development, strengthen the development of sports tourism industry, use the hand of sports tourism to pass on and develop the national sports culture of ancient villages with unique characteristics. All of these will push forward the process of new rural construction in the region.

\section{The Importance of Creative Development of Sports Tourism in Ancient Villages in Western Region of China}

The prominent feature of the population is big area inhabited by several nationalities and little region inhabited by their own in Xiangxi, and dominated by the Miao and Tujia ethnic groups, and the other ethnic minorities live together, and it also has rich and characteristic ancient village sports activities, enriching the daily life of local residents, and adding countless fun to foreign guests. At the same time, the Party and the state attach great importance to the development of the sports tourism industry under the new situation.

In the development of tourism industry, xiangxi puts sports tourism at a new strategic height. It is necessary to develop sports tourism with unique characteristics from different angles. The elements of "sport" and "tourism" appear to be irrelevant to the unified network structure system and creatively develop ancient villages favourable conditions and constraints. Based on strengths and weaknesses, the disadvantaged factors are transformed into superiority factors are to promote the transformation and upgrading of the sports tourism industry and to change the development direction in real time so as to create a distinctive sports tourism industry and comprehensively promote the development of tourism in the region.

The creative development of sports tourism in the ancient villages of Xiangxi will help to rescue, protect, inherit and develop the traditional national sports culture of ancient villages in a timely manner, which is conducive to promoting the development of tourism culture market in an all-round way, enhancing the core competitiveness of the tourism market and prompting the simultaneous development of tourism, sports and culture in the western Hunan and promoting the coordinated development of "economy, culture and ecology". 


\section{The Path of Creative Development of Sports Tourism in Ancient Village of Xiangxi}

Change of concept and focus on project planning and management of creative development. In the development of sports tourism industry, the government departments in xiangxi must keep pace with the times, change the traditional ideas, put the development of sports tourism in ancient villages as a top priority, and put a lot of "manpower, material resources and financial resources" on the basis of strong support. Scientifically guide the relevant tourism departments to unify the creative development and management of the ancient village sports tourism resources, purposefully and scientifically develop the existing special sports tourism resources in the ancient villages, and avoid the serious waste of sports tourism resources in the process of creative development.

The relevant tourism departments in Xiangxi should adhere to the principle of seeking truth from facts, adopt a variety of methods and means, understand deeply the specific situation of the development and utilization of the ancient village sports tourism resources in multi level, accurately grasp the development direction of the regional sports tourism industry, scientifically plan the creative development projects of the ancient village sports tourism, integrate the creative resources of sports tourism efficiently, standardized management is carried out on the basis of scientific application. In the process of rescue and protection of the national sports culture in the ancient villages, the "economic, social and ecological benefits" of the sports tourism creative development projects should be promoted in real time to provide favorable protection for the all-round development of the sports tourism industry.

Develop Sports Tourism Products with Characteristics based on the Development of the Times. In the process of creative development, Xiangxi should be based on the development requirements of The Times, use the vision of development, make overall plans and take all factors into consideration, understand deeply the difference in travel demand among travelers of different ages, locate ancient village sports tourism creative development accurately and promote objective, effective and satisfactory aesthetic, psychological and other needs of tourists at all levels in the practice of sports activities in ancient villages. Xiangxi should start from actual situation of the old village.

In the process of exploring the existing sports tourism resources in ancient villages, Xiangxi have vigorously developed creative product chains, such as miao drum ornaments and miao drum performing arts. Xiangxi should pay attention to sports culture consumption, use opportunely features of sports tourism resources, develop the sports products like characteristic folklore leisure, promote the tourists to enjoy the ancient village sports tourism scenery. Articipating in the practice of sports tourism can also stimulate cultural consumption. Purchase of creative sports tourism products with unique features of ancient villages can promote the economic development of the ancient villages and expand the tourist cultural market in the region. In addition, in the process of creative development, Xiangxi can also make use of the cultural connotation of the ancient villages to integrate the creative elements into the developed sports tourism products. The organic coupling of the two elements of "sports" and "tourism" can objectively present the connotation of the regional special national sports culture and traditional festivals, attract effectively the attention of travelers to stimulate their consumption and the characteristics of the ancient village of national culture can be spreaded to all corners of the world.

\section{Create Creative Brand, focus on Cooperation with Film Art \\ Create Creative Brand}

In the process of creative development, Xiangxi should pay attention to the creating of creative brand, which is the key point to develop sports tourism in ancient villages.Xiangxi should objectively analyze all kinds of problems that are prone to occur during the creative development of sports tourism resources in the ancient villages from the perspective of innovation.Xiangxi should optimize the sports tourism project of ancient villages and improve the brand effect by using modern means to dig up the sports tourism resources of ancient villages.

Take Miao Village as an Example, it has a wealth of natural sports sports tourism resources, traditional sports and cultural resources. In the process of creative development, Xiangxi should grasp the characteristics of Miaozhai sports tourism projects and culture, for example, it can 
reasonably develop the related sports tourism resources and build creative brand by the drum culture of Miao Village. In this process, Xiangxi can develop creatively a long history of drum culture and more events based on drum culture of Miao Village with the help of "xiangxi Tam international drum king competition", these activities can attractvtourists from all over the region, shape ancient villages sports tourism and brand, and form brand effect, in order to promote the development of sports tourism industry in ancient villages of Xiangxi and accelerate the development of regional tourism industry.

\section{Focus on Collaboration with Film and Television Acting Companies}

During creative development, Xiangxi should take the film and television art cooperation as one of the effective paths, develop the sports film and television art works with the characteristics of creativity, enhance the breadth and depth of the ancient villages in the development of sports tourism creativity, and present a rich and colorful national sports culture to people all over the world.

Xiangxi should cooperate with the film and television arts companies, such as the view to the ancient villages, shooting, etc., and creatively develop different forms of film and television art works, integrated ancient sports tourism elements skillfully into them, with the help of star effects and he existing geographical location, sports tourism resources objectively present the unique sports tourism resources in Xiangxi, for example, the sports activities project, which has prompted people of different levels in all regions to have a new understanding of sports tourism resources in ancient villages, especially the unique elements of ethnic culture. Xiangxi also can make use of the cooperation with the film and television arts so that the two major elements of sports culture and the film arets can be organically integrated to show the tourism characteristics of ancient villages.

Take "Yao ethnic group" as an example, in the creative development process, Xiangxi can use Yao ethnic major competition such as "The panwang festival" and "dragon boat race"and work with relevant film and television companies to integrate and innovate the sports brand activities with special features on the basis of maintaining original traditional characteristics, And take these works to different places and show to everyone. Xiangxi can also take advantage of microblogging and micromessaging, Optimize the marketing method, propagandize the ancient village sports tourism, effectively enhance the ancient village popularity. Let the moreand more tourists to visit the ancient village and have a sightseeing, experience the ancient village characteristic sports project, objectively present the sports tourism resource value of ancient village.

Integration with cultural and creative industries to train professional talents

In the process of creative development, western hunan should pay attention to the integration of ancient village sports tourism and cultural creative industry. From the perspective of cultural and creative industries, it needs objectively analyze all kinds of problems encountered in the creative development of ancient village sports tourism, optimize the path of creative development, effectively and creatively develop the sports tourism resources of ancient villages, integrate it into the development of regional cultural and creative industries, and promote the cultural creativity of the region Industrial development, with the help of cultural creativity, shaping the ancient village sports tourism brand.

In a sense, the creative development of the ancient village sports resources can't be separated from a number of high-level professionals. Xiangxi district government departments can cooperate with colleges in various areas, both will adjust their major and curriculum together, strengthen their practice base, and better participate in the development of sports tourism in ancient villages. It's aim to promote the creative development of sports tourism resources in ancient villages, effectively integrate the marketing and disseminate the sports tourism resources with the characteristics of ancient villages. Continuously upgrade the sports tourism industry and bring new vitality to the all-round development of tourism industry with the help of information technology.

\section{Conclusion}

In a word, the ancient village of Xiangxi is a core position in sports tourism development, Xiangxi should adhere to the principle of concrete analysis of specific problems, creatively exploit and 
efficiently utilize the existing sports tourism resources, create distinctive sports tourism, and inherit and protect the traditional ethnic sports culture in the ancient villages, in order to open up a completely new situation for the development of tourism industry and to promote tourism in the development of sports tourism industry to enter a higher stage. In this way, this can better highlight the characteristics of sports tourism in ancient villages and promote the healthy and stable development of the economy.

\section{Acknowledgements}

Scientific Research Project of Education Department of Hunan Province in 2017 (17C1331); Project of Evaluation Committee of Social Sciences in Hunan Province in 2017 (SXP17YBZC143).

\section{References}

[1] Tao Ping. Research on the Circular Economy Development of Rural Sports Tourism - Based on Low Carbon Ecology Perspective [J]. Journal of Shenyang Physical Education Institute, 2014,33 (02): 64-67

[2] Xiao Min. Developing Sports Tourism for the Coordinated Development of Sports and Sports Industry-Keynote address at the 2012 China Forum on Sports Tourism Development[ J]. Sports Culture Guide, 2013(2): 1-5

[3] Zhang Xiancheng, Su Xiuyan, Yang Kai. Research on the Development of Rural Sports Tourism and the Protection of Intangible Cultural Heritage in New Rural Construction[ J]. Shandong Institute of Physical Education Journal, 2010, 26(1): 18-23, 27

[4] Luo Yang. Study on Development and Countermeasure of Sports Tourism Industry in Xiangxi Based on SWOT Analysis [J]. Contemporary Sport Science and Technology, 2015,5 (23): 179-180

[5] Xi Xin. Ecological geography environment and optimization of leisure sports tourism in Xiangxi characteristic village[ J]. Contemporary Sports Technology, 2017, 7(21): 158-162

[6] Cai Dong, Chen Feng, Shi Min. Study on the Combination of Folk Sports Culture and Tourism in Xiangxi [J]. Fight Wushu Science, 2014,11 (6): 88-89 